\title{
Performance evaluation of tomato accessions across two locations of Khyber Pakhtunkhawa
}

\author{
Izhar Hussain ${ }^{1}$, Sher Aslam Khan ${ }^{1}$, Haneef Raza ${ }^{2 *}$, Ayub Khan ${ }^{1}$, Abid \\ Farid $^{1}$, Shah Masaud Khan ${ }^{1}$, Ijaz Hussain ${ }^{1}$, Naushad Ali ${ }^{1}$ and Ahmad \\ Ali $^{1}$ \\ 1. Department of Agricultural Sciences, University of Haripur Khyber Pakhtunkhwa-Pakistan \\ 2. Department of Plant Breeding and Genetics, Khyber Pakhtunkhwa Agricultural University, Peshawar-Pakistan \\ *Corresponding author's email: rhanif5@gmail.com
}

\section{Citation}

Izhar Hussain, Sher Aslam Khan, Haneef Raza, Ayub Khan, Abid Farid, Shah Masaud Khan, Ijaz Hussain, Naushad Ali and Ahmad Ali. Performance evaluation of tomato accessions across two locations of Khyber Pakhtunkhawa. Pure and Applied Biology. Vol. 6, Issue 2, pp657-663. http://dx.doi.org/10.19045/bspab.2017.60068

\begin{tabular}{llll}
\hline \hline Received: 08/02/2017 & Revised: 28/04/2017 & Accepted: 16/05/2017 & Online First: 19/05/2017 \\
\hline
\end{tabular}

\section{Abstract}

Identification of adaptable and stable genotypes is an important aspect of applied crop breeding which can insure sustainable crop production. Adaptability studies in tomato is an essential part of breeding for adequate evaluation of genotypes accomplished through environments (years/locations). A set of forty tomato accessions of diverse origin were tested at Swabi and Haripur locations to assess their performance. The experiment was carried out in randomized complete block design with three replications. Data were recorded on $50 \%$ flowering, days to fruiting and yield per hectare. Genotype (G), environment (E) and GEI share in total sum of squares were also studied. Significant $(p \leq 0.01)$ differences were observed among the accessions, environments (locations) and $\mathrm{G} \times \mathrm{E}$ interaction means for majority traits, which assured greater genetic variability among the accessions due to their divergent genetic make-up, as well as environments. On average, the accessions showed best performance in Swabi location than Haripur for yield and duration parameters. Overall, the promising accessions could be further explored for improvement in tomato fruit yield.

Keywords: Genotypes; Environments; Genotype-by-environment interaction

\section{Introduction}

Tomato (Solanum lycopersicum Mill.) is relatively a new addition to the world food crops, used in various forms both fresh and processed. Although tomato does not rank high in terms of caloric value, by virtue of volume consumed in its various forms such as cooked, salad, soup, preserves, pickles, ketchup sauces and many other products, it contributes substantially to dietary intake of vitamin $\mathrm{A}, \mathrm{B}, \mathrm{C}$ and essential minerals [1]. Tomato being a tender perennial crop, it is susceptible to both frost as well as high temperature, and thus it is grown under varying environmental conditions. Since 1961, tomato production in the world has increased 291\%, and during the year 2002 production reached 108 million metric tons. The share of Pakistan during 2005-06 in 
tomato production was 4965.35 tones, fresh or chilled worth US\$ 0.829 million [2].

In Pakistan, very little efforts have been made for improving vegetable crops including tomato, because of their secondary importance in the crop husbandry [3]. Consequently, very few local varieties of tomato are available for cultivation and most of them are selections from the introduced germplasm. Furthermore, the available varieties are poor in quality traits, and therefore, are unable to get consumer's attraction. In Pakistan tomato is grown on an area of 44460 hectare with annual production of 491370 tones [4]. Amongst the several reasons of low production of tomato the two reasons appears to be reasonable, firstly locally developed varieties are not available and secondly the non-existence of local tomato seed industry. Almost the total seed supply of tomato requirement is fulfilled through import of hybrid seed, and during 2005-06 Pakistan imported 72.75 tons of tomato seeds worth 2.09 million US\$, while it was increased significantly to US\$ 5.1 million in 2009 [5]. This expensive seed supply of tomato necessitates the vegetable breeders to breed varieties/hybrids having great yield potential under local environments. For this purpose, irrespective of the tools adopted during the breeding process, the breeder has to take two major steps: first to find and/or create genetic variation and secondly to select the best genotypes [4]. In present study, small samples of 40 tomato accessions were evaluated for their performance across two locations of Khyber Pakhtunkhawa.

\section{Material and methods}

The present investigation was conducted to categorize native and foreign tomato germplasms from diverse genetic sources. For morphological characterization tomato germplasm, consisting of 40 tomato genotypes, were acquired from national agriculture research center (NARC), Islamabad and federal Seed certification and registration department (FSC and RD), Islamabad, Pakistan in January, 2013 (Table 1).

Table 1. List of tomato accessions characterized various traits

\begin{tabular}{|c|c|c|c|c|c|}
\hline S. No. & Accession No. & Source & S. No. & Accession No. & Source \\
\hline 1 & Acc-06232 & **NARC (Pakistan) & 21 & AVR-211 & *AVRDC (Taiwan) \\
\hline 2 & Acc-10572 & NARC (Pakistan) & 22 & CLN-222 & USA \\
\hline 3 & Acc-10587 & NARC (Pakistan) & 23 & CLN-232 & USA \\
\hline 4 & Acc-17867 & NARC (Pakistan) & 24 & AVR-241 & AVRDC (Taiwan) \\
\hline 5 & Acc-17870 & NARC (Pakistan) & 25 & AVR-251 & AVRDC (Taiwan) \\
\hline 6 & Acc-17872 & NARC (Pakistan) & 26 & AVR-261 & AVRDC (Taiwan) \\
\hline 7 & Acc-17874 & NARC (Pakistan) & 27 & CLN-272 & USA \\
\hline 8 & Acc-17877 & NARC (Pakistan) & 28 & CLN-282 & USA \\
\hline 9 & Acc-17878 & NARC (Pakistan) & 29 & CLN-292 & USA \\
\hline 10 & Acc-17879 & NARC (Pakistan) & 30 & EUR-303 & Holand \\
\hline 11 & Acc-17882 & NARC (Pakistan) & 31 & CLN-312 & USA \\
\hline 12 & Acc-17883 & NARC (Pakistan) & 32 & AVR-321 & AVRDC (Taiwan) \\
\hline 13 & Acc-17889 & NARC (Pakistan) & 33 & EUR-333 & Holland \\
\hline 14 & Acc-17890 & NARC (Pakistan) & 34 & AVR-341 & AVRDC (Taiwan) \\
\hline 15 & Acc-19288 & NARC (Pakistan) & 35 & CLN-352 & USA \\
\hline 16 & Acc-19289 & NARC (Pakistan) & 36 & CLN-362 & USA \\
\hline 17 & Acc-19290 & NARC (Pakistan) & 37 & STM-1 & Swabi (Pakistan) \\
\hline 18 & Acc-19893 & NARC (Pakistan) & 38 & STM-2 & Swabi (Pakistan) \\
\hline 19 & Acc-19912 & NARC (Pakistan) & 39 & STM-3 & Swabi (Pakistan) \\
\hline 20 & AVR-201 & AVRDC (Taiwan) & 40 & Sahel & Syngenta \\
\hline AVRDC & Asian Vegetable Research and Development Center, NARC & National Agriculture Research Center
\end{tabular}




\section{Nursery preparation}

Sowing of the accessions was done at Agriculture Research Farm, University of Haripur, in February 2013 for raising nursery seedlings. For sowing different soils like sandy, light, well drained and high in organic matter were selected by keeping a row to row distance of $10 \mathrm{~cm}$ and plant-toplant distance of $5 \mathrm{~cm}$.

\section{Transplantation}

Transplantation of the seedlings was carried out into well prepared field plots rich in organic matter after 4 weeks from the nursery at the evening time so to reduce the risk of transplant shock. Each field plot was composed of 4 rows of 1 meter with a row to row distance of $120 \mathrm{~cm}$ and a plant to plant space of $40 \mathrm{~cm}$.

\section{Field management}

FYMs [(@15 tones per hectare) and NPK (@ 100:80:60 kg per hectare)] was applied at the time of seed bed preparation, followed by irrigation. Total amount of organic manure, $\mathrm{P}_{2} \mathrm{O}_{5}, \mathrm{~K}_{2} \mathrm{O}$ and $1 / 3 \mathrm{~N}$ was applied at the time of seed bed preparation and the rest of nitrogen was side dressed in two splits i.e., 20 days after transplantation and at preflowering stage. Furadon granules were also applied to the soil before transplantation to aviod any insect attack on young plantlets. In order to keep the block weed free, mechanical weeding was done from transplantation till harvest. Earthing up and supporting and training with vertical strings was done after $15^{\text {th }}$ day of transplantations.

\section{Traits measurement and statistical analysis}

Data were recorded on days to $50 \%$ flowering, days to fruiting and yield per hactare. Data were subjected to analysis of variance (ANOVA) according to Steel \& Dickey [6]. After getting the significant variations among genotypes performance for various parameters, the means for each trait were further separated and compared by using the least significant difference (LSD) test at $5 \%$ level of probability.

\section{Results and discussion}

Pooled analysis of variance across two locations revealed significant $(p<0.01)$ differences among genotypes, environment and genotype $\times$ environment interaction for days to $50 \%$ flowering and yield per hectare; however environment and genotype $x$ environment interaction was non-significant for days to fruiting(Table 2).Similar results were out lined by Panthee et al. [7].

Table 2. Mean square values of ANOVA for yield and yield related traits of 40 Accessions across two location of Khyber Pakhtunkhwa

\begin{tabular}{|l|l|l|l|l|}
\hline \multirow{2}{*}{ Parameters } & \multicolumn{2}{|l|}{ Mean squares } & \multirow{2}{*}{ CV (\%) } \\
\cline { 2 - 4 } & Locations & Genotypes & $\mathbf{G} \times \mathbf{L}$ & \\
\hline d.f. & 1 & 39 & 39 & \\
\hline Days to germination & $0.33750^{* *}$ & $6.19135^{* *}$ & $1.10673^{* *}$ & 3.45 \\
\hline Days to 50\% Flowering & $49.504^{* *}$ & $59.849^{* *}$ & $16.111^{* *}$ & 1.49 \\
\hline Days to Fruiting & $42.504^{* *}$ & $36.668^{* *}$ & $18.12^{* *}$ & 3.26 \\
\hline Yield per Plot & $8.0656^{* *}$ & $4.4246^{* *}$ & $3.1279^{* *}$ & 6.41 \\
\hline
\end{tabular}

**, Significant at $p \leq 0.01$

\section{Days to $50 \%$ flowering}

Category wise comparison for mean ranges at both locations were Acc-17889 (41.00) to STM-2 (52.00) days in indigenous group, EUR-333 (46.00) to EUR-303 (53.00 days) in European, AVR-241 (43.17) to AVR-261 (50.84 days) in Taiwan and CLN-282 (43.50 days) to CLN-312 (54.67 days) days in American germplasm. Mean values for locations based on 40 tomato genotypes for 
days to $50 \%$ flowering was 47.37 and 48.27 days under Haripur and Swabi environment, respectively, indicating a net difference of 0.92 days between two tested environments (Table 3). Similarly Ghosh et al. [8] reported a wide range of variation for days to initial flowering in tomato. Wider variation in respect to days to first flowering was also reported by Prema et al. [9] among six cherry tomato lines. This scenario was manifested in Tropimech which has shorter days to flowering and performs better than the other genotypes in terms of yield. Similar results have been reported by Dhankhar \& Dhankhar [10]. Comparison between the environments showed that genotype EUR-312 revealed maximum (54.67 days) in Haripur environment followed by the same genotype in Swabi location; however, lowest (42.33 days) were observed in Swabi.

Table 3. Days to $50 \%$ flowering, days to fruiting and yield per hectare (tons) comparison of 40 Accessions across two locations of Khyber Pakhtunkhwa

\begin{tabular}{|c|c|c|c|c|c|c|c|c|c|}
\hline \multicolumn{3}{|c|}{ Days to $50 \%$ flowering } & \multicolumn{3}{|c|}{ Days to fruiting } & \multicolumn{4}{|c|}{ Yield per hectare (tons) } \\
\hline Accessions & Haripur & Swabi & Mean & Haripur & Swabi & Mean & Haripur & Swabi & Mean \\
\hline Europe & 49.67 & 50.17 & 49.92 & 19.67 & 20.33 & 20.00 & 33.10201 & 20.57801 & 26.84001 \\
\hline EUR-303 & 53.33 & 53.67 & $53.50 \mathrm{ab}$ & 23.33 & 23.00 & $23.17 \mathrm{~b}$ & 33.01929 & 17.76045 & $25.38987 \mathrm{e} / \mathrm{k}$ \\
\hline EUR-333 & 46.00 & 46.67 & $46.34 \mathrm{kl}$ & 16.00 & 17.67 & $16.84 \mathrm{n} / \mathrm{p}$ & 33.18474 & 23.39556 & $28.29015 \mathrm{c} / \mathrm{f}$ \\
\hline Indigenous & 47.43 & 47.96 & 47.70 & 17.81 & 18.13 & 17.97 & 24.78620 & 30.05211 & 27.41916 \\
\hline Acc-06232 & 50.33 & 50.67 & $50.50 \mathrm{c} / \mathrm{f}$ & 20.33 & 20.67 & $20.50 \mathrm{c} / \mathrm{g}$ & 22.54043 & 16.75183 & $19.64613 n$ \\
\hline Acc-10572 & 46.33 & 49.67 & $48.00 \mathrm{~h} / \mathrm{j}$ & 16.33 & 20.67 & $18.50 \mathrm{k} / \mathrm{m}$ & 25.56827 & 25.13373 & $25.35100 \mathrm{e} / \mathrm{k}$ \\
\hline Acc-10587 & 45.33 & 50.67 & $48.00 \mathrm{~h} / \mathrm{j}$ & 15.33 & 20.67 & $18.001 / \mathrm{n}$ & 26.41743 & 28.72768 & $27.57256 \mathrm{c} / \mathrm{h}$ \\
\hline Acc-17867 & 42.33 & 43.00 & $42.67 \mathrm{o}$ & 14.00 & 15.33 & $14.67 \mathrm{rs}$ & 24.57162 & $3+.50$ & $9.47717 \mathrm{~cd}$ \\
\hline Acc-17870 & 51.67 & 47.33 & $49.50 \mathrm{e} / \mathrm{h}$ & 21.67 & 17.33 & $19.50 \mathrm{f} / \mathrm{k}$ & 26.37357 & 31.76151 & $29.06754 \mathrm{c} / \mathrm{e}$ \\
\hline Acc-17872 & 43.00 & 45.67 & $44.34 \mathrm{mn}$ & 14.33 & 16.33 & $15.33 q \mathrm{qr}$ & 749 & 28.7 & $47 \mathrm{e} / \mathrm{k}$ \\
\hline Acc-17874 & 50.00 & 48.67 & $49.34 \mathrm{e} / \mathrm{h}$ & 20.00 & 18.67 & $19.34 \mathrm{~g} / \mathrm{k}$ & 20.06871 & 33.46380 & $26.76626 \mathrm{~d} / \mathrm{i}$ \\
\hline Acc-17877 & 53.00 & 43.00 & $48.00 \mathrm{~h} / \mathrm{j}$ & 23.00 & 14.67 & $18.84 \mathrm{j} / 1$ & 24.94038 & 30.79076 & $27.86557 \mathrm{c} / \mathrm{g}$ \\
\hline Acc-17878 & 47.67 & 44.33 & $46.00 \mathrm{kl}$ & 17.67 & 15.33 & $16.50 \mathrm{o} / \mathrm{q}$ & 21.08331 & 52.14517 & $36.61424 b$ \\
\hline Acc-17879 & 46.00 & 51.33 & $48.67 \mathrm{~g} / \mathrm{j}$ & 16.00 & 20.67 & $18.34 \mathrm{k} / \mathrm{m}$ & 24.61746 & 23.87993 & $24.24870 \mathrm{~g} / \mathrm{m}$ \\
\hline Acc-17882 & 51.33 & 49.33 & $50.33 \mathrm{~d} / \mathrm{f}$ & 21.33 & 18.33 & $19.83 \mathrm{e} / \mathrm{j}$ & 25.45665 & 27.13502 & $26.29584 \mathrm{~d} / \mathrm{j}$ \\
\hline Acc-17883 & 52.67 & 48.00 & $50.34 \mathrm{~d} / \mathrm{f}$ & 22.67 & 18.00 & $20.34 \mathrm{c} / \mathrm{h}$ & 27.24266 & 29.55291 & $28.39779 \mathrm{c} / \mathrm{f}$ \\
\hline Acc-17889 & 40.33 & 41.67 & $41.00 \mathrm{p}$ & 13.33 & 14.33 & $13.83 \mathrm{~s}$ & 28.85924 & 30.58545 & $29.72235 \mathrm{~cd}$ \\
\hline Acc-17890 & 45.00 & 47.00 & $46.00 \mathrm{kl}$ & 15.00 & 16.33 & $15.67 \mathrm{p} / \mathrm{r}$ & 22.84740 & 32.00270 & $27.42505 \mathrm{c} / \mathrm{h}$ \\
\hline Acc-19288 & 47.00 & 52.33 & $49.67 \mathrm{e} / \mathrm{g}$ & 17.00 & 21.33 & $19.17 \mathrm{~h} / 1$ & 20.50525 & 27.35429 & $23.92977 \mathrm{~h} / \mathrm{m}$ \\
\hline
\end{tabular}




\begin{tabular}{|c|c|c|c|c|c|c|c|c|c|}
\hline Acc-19289 & 43.67 & 45.00 & $44.34 \mathrm{mn}$ & 15.00 & 16.33 & $15.67 \mathrm{p} / \mathrm{r}$ & 20.54113 & 28.96688 & $24.75401 \mathrm{f} / 1$ \\
\hline Acc-19290 & 48.67 & 52.33 & $50.50 \mathrm{c} / \mathrm{f}$ & 18.67 & 22.67 & $20.67 \mathrm{c} / \mathrm{f}$ & 20.35176 & 26.20414 & $23.27795 \mathrm{i} / \mathrm{n}$ \\
\hline Acc-19893 & 51.67 & 51.33 & $51.50 \mathrm{~cd}$ & 21.67 & 16.67 & $19.17 \mathrm{~h} / 1$ & 24.80085 & 32.95750 & $28.87918 \mathrm{c} / \mathrm{e}$ \\
\hline Acc-19912 & 46.33 & 51.00 & $48.67 \mathrm{~g} / \mathrm{j}$ & 16.33 & 21.67 & $19.00 \mathrm{i} / 1$ & 27.23070 & 28.00012 & $27.61541 \mathrm{c} / \mathrm{h}$ \\
\hline Sahel & 43.33 & 44.67 & $44.00 \mathrm{~m} / \mathrm{o}$ & 14.67 & 14.67 & $14.67 \mathrm{rs}$ & 42.96993 & 48.85021 & $45.91007 \mathrm{a}$ \\
\hline STM-1 & 48.33 & 46.67 & $47.50 \mathrm{i} / \mathrm{k}$ & 18.33 & 16.67 & $17.50 \mathrm{~m} / \mathrm{o}$ & 18.87272 & 25.14768 & $22.01020 \mathrm{k} / \mathrm{n}$ \\
\hline STM-2 & 51.33 & 52.67 & $52.00 \mathrm{bc}$ & 21.33 & 21.67 & $21.50 \mathrm{c}$ & 25.38688 & 27.42605 & $26.40647 \mathrm{~d} / \mathrm{j}$ \\
\hline STM-3 & 45.67 & 46.67 & $46.17 \mathrm{kl}$ & 15.67 & 18.00 & $16.84 \mathrm{n} / \mathrm{p}$ & 27.20877 & 21.18298 & $24.19588 \mathrm{~g} / \mathrm{m}$ \\
\hline Taiwan & 45.43 & 48.05 & 46.74 & 16.14 & 19.14 & 17.64 & 29.28325 & 28.60580 & 28.94453 \\
\hline AVR-201 & 48.33 & 52.67 & $50.50 \mathrm{c} / \mathrm{f}$ & 18.33 & 22.00 & $20.17 \mathrm{~d} / \mathrm{i}$ & 33.03524 & 29.25990 & $31.14757 \mathrm{c}$ \\
\hline AVR-211 & 45.33 & 47.00 & $46.17 \mathrm{kl}$ & 15.33 & 22.67 & $19.00 \mathrm{i} / 1$ & 27. & 3 & $1 / j$ \\
\hline AVR-241 & 43.00 & 43.33 & 43.17 no & 14.33 & 20.67 & $17.50 \mathrm{~m} / \mathrm{o}$ & 33.42792 & 44.09615 & $04 \mathrm{~b}$ \\
\hline AVR-251 & 45.67 & 52.33 & $49.00 \mathrm{f} / \mathrm{i}$ & 16.00 & 15.00 & $15.50 \mathrm{qr}$ & 32.19805 & 21.08730 & $26.64268 d / j$ \\
\hline AVR-261 & 50.67 & 51.00 & $50.84 \mathrm{c} / \mathrm{e}$ & 20.67 & 21.67 & $21.17 \mathrm{~cd}$ & 30.89442 & 40.18925 & 35.5418 \\
\hline AVR-321 & 43.33 & 44.67 & $44.00 \mathrm{~m} / \mathrm{o}$ & 14.67 & 15.67 & $15.17 \mathrm{r}$ & 27.82471 & 18.37838 & $23.10155 \mathrm{i} / \mathrm{n}$ \\
\hline AVR-341 & 41.67 & 45.33 & 43.50no & 13.67 & 16.33 & $15.00 \mathrm{rs}$ & 20.40359 & 22.12582 & $21.264711 / \mathrm{n}$ \\
\hline USA & 48.29 & 48.92 & 48.61 & 18.38 & 18.88 & 18.63 & 25.97890 & 25.52567 & 25.75229 \\
\hline CLN-222 & 46.00 & 44.67 & $45.341 \mathrm{~m}$ & 16.00 & 17.00 & $16.50 \mathrm{o} / \mathrm{q}$ & 34.72956 & 25.07991 & $29.90474 \mathrm{~cd}$ \\
\hline CLN-232 & 49.67 & 49.33 & $49.50 \mathrm{e} / \mathrm{h}$ & 19.67 & 15.33 & $17.50 \mathrm{~m} / \mathrm{o}$ & 31.51832 & 27.67720 & $29.59776 \mathrm{~cd}$ \\
\hline CLN-272 & 52.00 & 51.00 & $51.50 \mathrm{~cd}$ & 22.00 & 20.00 & $21.00 \mathrm{c} / \mathrm{e}$ & 21.85074 & 23.68459 & $22.76767 \mathrm{j} / \mathrm{n}$ \\
\hline CLN-282 & 44.33 & 42.67 & $43.50 \mathrm{no}$ & 15.00 & 14.67 & $14.84 \mathrm{rs}$ & 25.66196 & 29.08448 & $27.37322 \mathrm{c} / \mathrm{h}$ \\
\hline CLN-292 & 47.00 & 47.67 & $47.34 \mathrm{jk}$ & 17.00 & 18.00 & $17.50 \mathrm{~m} / \mathrm{o}$ & 17.49534 & 23.99355 & $20.74445 \mathrm{mn}$ \\
\hline CLN-312 & 55.00 & 54.33 & $54.67 \mathrm{a}$ & 25.00 & 24.33 & $24.67 \mathrm{a}$ & 20.65674 & 19.20959 & $19.93317 n$ \\
\hline CLN-352 & 45.67 & 52.33 & $49.00 \mathrm{f} / \mathrm{i}$ & 15.67 & 22.33 & $19.00 \mathrm{i} / 1$ & 37.90690 & 24.52178 & $31.21434 \mathrm{c}$ \\
\hline CLN-362 & 46.67 & 49.33 & $48.00 \mathrm{~h} / \mathrm{j}$ & 16.67 & 19.33 & $18.001 / \mathrm{n}$ & 18.01161 & 30.95422 & $24.48292 \mathrm{f} / \mathrm{m}$ \\
\hline
\end{tabular}

\section{Days to fruiting}

Mean values for tomato accessions for days to fruiting were 17.72 and 18.57 days under Haripur and Swabi environment, respectively, indicating a net difference of 0.85 days between two tested environments (Table 3). This character showed wide range of variation provides ample scope for selecting the desirable genotypes. Minimum numbers of days to fruiting (13.83 days) were observed for genotype Acc-17889 followed by Sahel and Acc-17867 (14.67 days), CLN-282 (14.84 days) and AVR-321 (15.17 days). These genotypes were early 
maturing by taking less days to maturity. Whereas, maximum value of (24.67 days) was observed for CLN-312 followed by EUR-303 (23.17 days), STM-2 (21.50 days) and AVR-261 (21.17 days). These were grouped in late maturing. Similar trend was also observed by Sunnadagudi [11] in tomato. Comparison between the environments showed that genotype EUR303 revealed maximum number of days to fruiting (23.33 days) in Haripur environment. However, in Swabi the genotype CLN-312 revealed maximum days to fruiting with a mean value of 24.33. Category wise, over all mean across two locations ranged between Acc-17889 (13.83) to STM-2 (21.50 days) for indigenous group, EUR-333 (16.84) to EUR-303 (23.17 days) for European, AVR341 (15.00) to AVR-261 (21.17 days) for Taiwan and CLN-282 (14.84) to CLN-312 (24.67 days) for American germplasm.

\section{Yield hectare $^{-1}$ (tons)}

Mean values of 40 tomato genotypes for yield per hactare was 26.22 and 28.42 tons per hectare under Haripur and Swabi environment, respectively, indicating a net difference of 2.20 tons between two tested environments (Table 3). Maximum value of 45.91 tons per hectare were observed in Sahel followed by AVR-241 (38.76), Acc17878 (36.61), AVR-261 (35.54) and CLN352 (31.21) whereas, minimum (19.65 tons) was observed for Acc-06232 followed by CLN-312 (19.93), CLN-292 (20.74), AVR341 (21.26) and STM-1 (22.01) for yield per hectare (Table 3 ). A wide range of yield/ha ( 27.91 to $75.55 \mathrm{t} / \mathrm{ha}$ ) was also reported in six cherry tomato lines by Ingale [12] Comparison between the environments showed that genotype Acc-17878 revealed maximum (52.14 tons) yield per hectare in Swabi environment followed by the Sahel genotype in the same location with an average yield of 48.85 tons per hectare; however, minimum (17.49 tons) yield per hectare was observed in Swabi. Indigenous, European, Taiwan and USA group ranged from 19.64 ton (Acc-06232) to 36.61 ton (Acc-17878), 25.38 ton (EUR-303) to 28.29 ton (EUR-333), 21.26 ton (AVR-341) to 38.76 ton (AVR- 241) and 19.93 ton (CLN292) to 29.90 tons (CLN-222), respectively. Fruit yield is the final products of various characters and here it was considered to be the resultant variable while the rest of the variables were casual variables. Each character influence fruit yield by its direct and indirect contributions with other characters. An aggregate residual factor that includes all other factors affecting fruit yield and not yet accounted was treated as independent of the rest of factors considered.

\section{Conclusions}

Based on two-location studies, it was concluded that environments in combination with genotypes play principal role in phenotypic manifestation of the various traits followed by $\mathrm{G} \times \mathrm{E}$ interaction. Overall, accession Sahel followed by STM-3 and AVR-321 showed best performance and found more adaptive to the existing environmental conditions of Swabi. These accessions could be grown for improvement in fruit yield of tomato.

\section{Authors' contributions}

Conceived and designed the experiments: I Hussain, Performed the Experiments: N Ali \& A Ali, Analyzed the Data: A Farid, Contributed reagents/ materials/ analysis tools: SM Khan, I Hussain, N Ali and A Ali, Wrote the paper: SA Khan, A Khan, SM Khan \& H Raza.

\section{References}

1. Tigchelaar EC (1986). Tomato Breeding. In: Vegetable Breeding. Mark J. Bassett (Ed). AVI publishing Co Inc Westport Connecticut p.137.

2. Anonymous (2006). Fruit, Vegetables and Condiments Statistics of Pakistan 2005-06. Government of Pakistan 
Ministry of Foods, Agriculture and Livestock (Economic Wing) Islamabad.

3. Shokat S, Azhar FM \& Zia MB (2011). Path coefficient analysis of total soluble solids in Solanum lycopersicum L. The Nucleus 48(4): 339-342.

4. Passam HC, Karapanos IC, Bebeli PJ \& Savvas D (2007). A Review of Recent Research on Tomato Nutrition, Breeding and Post-Harvest Technology with Reference to Fruit Quality. The European J Plant Sci \& Biotec 1(1): 1-21.

5. Anonymous. (2011). Tomato crop status, Pakistan Rain/Flood. Report on Flash floods, breaches in canals and damage to infrastructure and agriculture sectors in Sind Province 24 September.

6. Steel RG \& Dickey JH (1997). Pinciples and procedures of statistics a biometrical approach (No. 519.5 S8).

7. Panthee DR, Brown AF, Yousef GG, Ibrahem R \& Anderson C (2013). Novel molecular marker associated with Tm2a gene conferring resistance to tomato mosaic virus in tomato. Plant Breeding. 132(4): 413-416.
8. Ghosh KP, Islam AKMA, Mian MAK \& Hossain MM (2010). Variability and Character Association in $F_{2}$ Segregating Population of Different Commercial Hybrids of Tomato (Solanum lycopersicum L.). J Applied Sci and Environ Manag 14(2): 91-95.

9. Prema G, Indiresh KK \& Santosha HM (2011b). Evaluation of cherry tomato (Solanum lycopersicum var. cerasiforme) genotypes for growth, yield and quality traits. Asian J Hort 6(1): 181-184.

10. Dhankhar SK \& Dhankhar BS (2006). Variability, heritability, correlation and path-coefficient studies in tomato. Haryana J Hort Sci 35(1/2): 179.

11. Sunnadagudi RB (2011). Molecular, morphological and chemical characterization of tomato (Solanum lycopersicumL.) genotypes and influence of different organic manures on seed yield, quality in tomato cv. Dmt-2. M.Sc Thesis Univ Agric Sci Dharwad India.

12. Ingale BV (1993). Diversity, heterosis and genetics of yield and quality parameters in brinjal (Solanum melongena L.) Univ Agric Sci. 